\title{
Synthesis and Electrochemical Properties of $\mathrm{LiFeBO}_{3}$ and $\mathrm{LiFeBO}_{3} / \mathrm{C}$ composite
}

\author{
Lin $\mathrm{Li}^{\mathrm{a}}$, Jinsong Cheng ${ }^{\mathrm{b}}$, Qing $\mathrm{Liu}^{\mathrm{c}}$, Ting Wang ${ }^{\mathrm{d}}$, Rongfei Zhao ${ }^{\mathrm{e}}$, Hao Zheng ${ }^{\dagger}$ \\ Key Laboratory of Functional Materials and Chemistry for Performance and Resource of Guizhou \\ Education Department, Anshun University, Anshun 561000, China \\ alilin404003375@qq.com, b496063041@qq.com, ${ }^{\text {c3 } 390516278 @ q q . c o m, ~ d 85828082 @ q q . c o m, ~}{ }^{\circ} 447$ \\ 23318@qq.com, 'zhengaho1986@126.com
}

Keywords: $\mathrm{LiFeBO}_{3}$, carbon-coated, Lithium-ion battery, cathode material.

\begin{abstract}
Carbon-coated $\mathrm{LiFeBO}_{3}$ composite material was prepared by a rheological phase reaction method and successive annealing procedure. In the synthesis procedure, citric acid was selected as carbon source. The structures and morphologies of $\mathrm{LiFeBO}_{3}$ and carbon-coated $\mathrm{LiFeBO}_{3}$ samples were characterized by X-ray diffraction (XRD) and scanning electron microscopy (SEM) techniques. The effect of carbon coating and the annealing temperature on the structure and electrochemical properties have also been investigated. The electrochemical tests showed that the carbon-coated $\mathrm{LiFeBO}_{3}$ could greatly improve the discharge capacity, rate capability and cycling stability due to the improved electric conductivity. The carbon-coated sample $\left(\mathrm{LiFeBO}_{3} / \mathrm{C}\right)$ shows good electrochemical performance (the initial discharge capacity of $139.7 \mathrm{mAh} \mathrm{g}^{-1}$ at $5 \mathrm{~mA} / \mathrm{g}$ ). These results indicate that the carbon-coated $\mathrm{LiFeBO}_{3}$ could be a promising cathode material for lithium ion batteries.
\end{abstract}

\section{Introduction}

Lithium metal borates $\mathrm{LiMBO}_{3}(\mathrm{M}=\mathrm{Mn}, \mathrm{Fe}, \mathrm{Co}, \mathrm{Zn})$ have received much attention because the lightest polyanion group $\left(\mathrm{BO}_{3}{ }^{-}\right)$is expected to provide higher theoretical energy density (222 $\mathrm{mA} \mathrm{h} \mathrm{g}^{-1}$ ) than other polyanion cathode materials ${ }^{[1-4]}$. Furthermore, boron is relatively abundant in the earth's crust and more environment-friendly compared with phosphorous. Legagneur et al. ${ }^{\text {[5] }}$ had reported the structural data and lithium insertion/deinsertion properties of $\mathrm{LiMBO}_{3}(\mathrm{M}=\mathrm{Mn}, \mathrm{Fe}$, Co) as new cathode materials. One disappointing result is concluded that only a very small amount of lithium (less than $0.04 \mathrm{Li}$ per formula unit) was reinserted reversibly from the three compounds. However, Dong et al. ${ }^{[8]}$ reported the electrochemical performance of $\mathrm{LiFeBO}_{3}$, which demonstrates the discharge plateau potential of about $2.3 \mathrm{~V}$, and initial discharge-specific capacity of $91.8 \mathrm{~mA} \mathrm{~h} \mathrm{~g}^{-1}$. In the report, the $\mathrm{LiFeBO}_{3}$ sample exhibits better capacity retention after initial two first cycles. The structural study shows that a new ternary compound $\mathrm{A}\left(\mathrm{Li}_{2} \mathrm{O}, \mathrm{FeO}\right.$ and $\mathrm{B}_{2} \mathrm{O}_{3}$ in a 2:1:1 molar ratio) could be found. Therefore, the studies for $\mathrm{LiFeBO}_{3}$ are now in progress, including crystal structure and electrochemical performance.

Carbon coating of polyanion cathode materials enables to produce nanoparticle electrode materials coated with nonocarbon layers at a single cast. Carbon particles cure poor particle contact and particle surface disorder of electrode materials, which improve $\mathrm{Li}^{+}$ion transport and conductivity.

In this work, we have prepared $\mathrm{LiFeBO}_{3}$ and carbon-coated $\mathrm{LiFeBO}_{3}$ composites using the rheological phase reaction method and successive calcination procedure. When the prepared materials were evaluated as cathode for lithium ion batteries, they shows good electrochemical performance, in terms of rate capability, and cycling stability.

\section{Experimental}

Synthesis and characterization of the samples. All chemicals were of analytical grade and were used without further purification. At first, $\mathrm{LiOH} \cdot 2 \mathrm{H}_{2} \mathrm{O}, \mathrm{FeC}_{2} \mathrm{O}_{4} \cdot 4 \mathrm{H}_{2} \mathrm{O}$, and $\mathrm{H}_{3} \mathrm{BO}_{3}$ in the molar ratio of 1:1:1 were mechanically mixed with an agate mortar by adding water to obtain a 
rheological mixture. An appropriate amount of citric acid (ca. $25 \mathrm{~mol} \%$ of total metal ions present in the mixture) was used as a carbon source for the preparation of the carbon-coated samples. The rheological phase mixtures were heated at $100{ }^{\circ} \mathrm{C}$ for $12 \mathrm{~h}$ to obtain the precursors. The precursors were firstly calcined at $350{ }^{\circ} \mathrm{C}$ for $3 \mathrm{~h}$ and then heated at $650^{\circ} \mathrm{C}$ for $12 \mathrm{~h}$ under argon atmosphere. For convenience, samples were labeled as and $\mathrm{LiFeBO}_{3} / \mathrm{C}$.

$\mathrm{LiOH} \cdot 2 \mathrm{H}_{2} \mathrm{O}, \mathrm{FeC}_{2} \mathrm{O}_{4} \cdot 4 \mathrm{H}_{2} \mathrm{O}$, and $\mathrm{H}_{3} \mathrm{BO}_{3}$ in the molar ratio of 1:1:1 were mechanically mixed with an agate mortar by adding water to obtain a rheological mixture. The rheological phase mixtures were heated at $100{ }^{\circ} \mathrm{C}$ for $12 \mathrm{~h}$ to obtain the precursors. The precursors were firstly calcined at $350{ }^{\circ} \mathrm{C}$ for $3 \mathrm{~h}$ and then heated at $650^{\circ} \mathrm{C}$ for $12 \mathrm{~h}$ under argon atmosphere. For convenience, samples were labeled as $\mathrm{LiFeBO}_{3}$.

Powder X-ray diffraction patterns of the samples were obtained with a Rigaku XRD diffractometer using Ni-filtered $\mathrm{Cu} \mathrm{K \alpha}$ radiation. The morphologies of the samples were observed by using a scanning electron microscope (SEM; LEO 1530VP, Germany).

Electrochemical measurements. Electrochemical performances of these samples were tested in a model test cell system. Positive electrodes were prepared by pressing the mixtures of the active material (70\%), acetylene black (20\%), and polytetrafluoroethylene (PTFE) (10\%) onto a nickel grid. Prior to being used, the positive electrodes were dried at $125{ }^{\circ} \mathrm{C}$ in a vacuum furnace for $24 \mathrm{~h}$. The electrolyte was a solution of $1 \mathrm{M} \mathrm{LiPF}_{6} /$ ethylene carbonate (EC) and diethyl carbonate (DEC) (1:1 by volume). The separator was Celgard 2400 porous polypropylene. The counter and reference electrodes were lithium foil. The model test cells were assembled in an argon-filled dry box. Charge-discharge tests were carried out at different current densities in the range of $1.0 \mathrm{~V}$ to $4.6 \mathrm{~V}$.

\section{Results and discussion}

The crystallographic structures of the $\mathrm{LiFeBO}_{3}$ and $\mathrm{LiFeBO}_{3} / \mathrm{C}$ samples are first confirmed by XRD analysis as shown in Figure 1. The diffraction peaks of sample can be indexed as monoclinic $\mathrm{LiFeBO}_{3}$ with cell parameters $a=5.166(2) \AA$, and the space group was derived to be $C 2 / c$. The observed XRD patterns were well consistent with the previously reported patterns ${ }^{[5]}$.

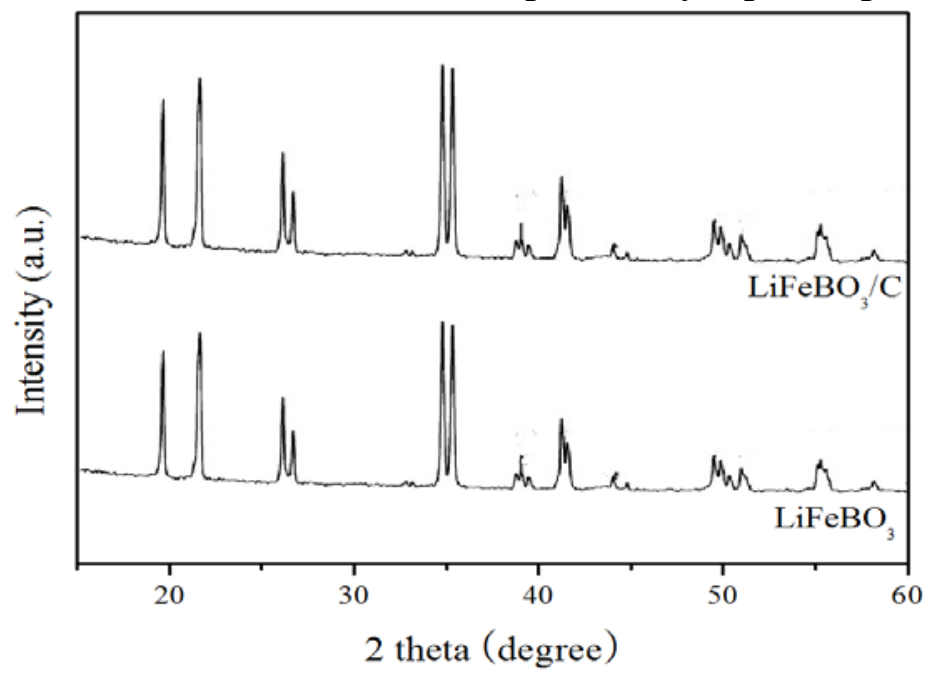

Fig. 1. XRD patterns of $\mathrm{LiFeBO}_{3}$ and $\mathrm{LiFeBO}_{3} / \mathrm{C}$.

The surface morphological features of $\mathrm{LiFeBO}_{3}$ and $\mathrm{LiFeBO}_{3} / \mathrm{C}$ were investigated by SEM. As shown in Fig.2, they are all composed of non-uniform particles with different sizes. From Fig. $2 \mathrm{~b}$ and $2 \mathrm{~d}$, it can be observed that the particles of the bare $\mathrm{LiFeBO}_{3}$ sample were agglomerated with the particles sized with ca. $0.5-8 \mu \mathrm{m}$, which were much larger than those of $\mathrm{LiFeBO}_{3} / \mathrm{C}$. Fig $2 \mathrm{~d}$ shows that the particle size of $\mathrm{LiFeBO}_{3} / \mathrm{C}$ is in the range of $0.1-0.8 \mu \mathrm{m}$. The grain size and crystallinity of $\mathrm{LiFeBO}_{3} / \mathrm{C}$ were enhanced with increasing of synthesis temperatures, which is well consistent with the XRD results. 


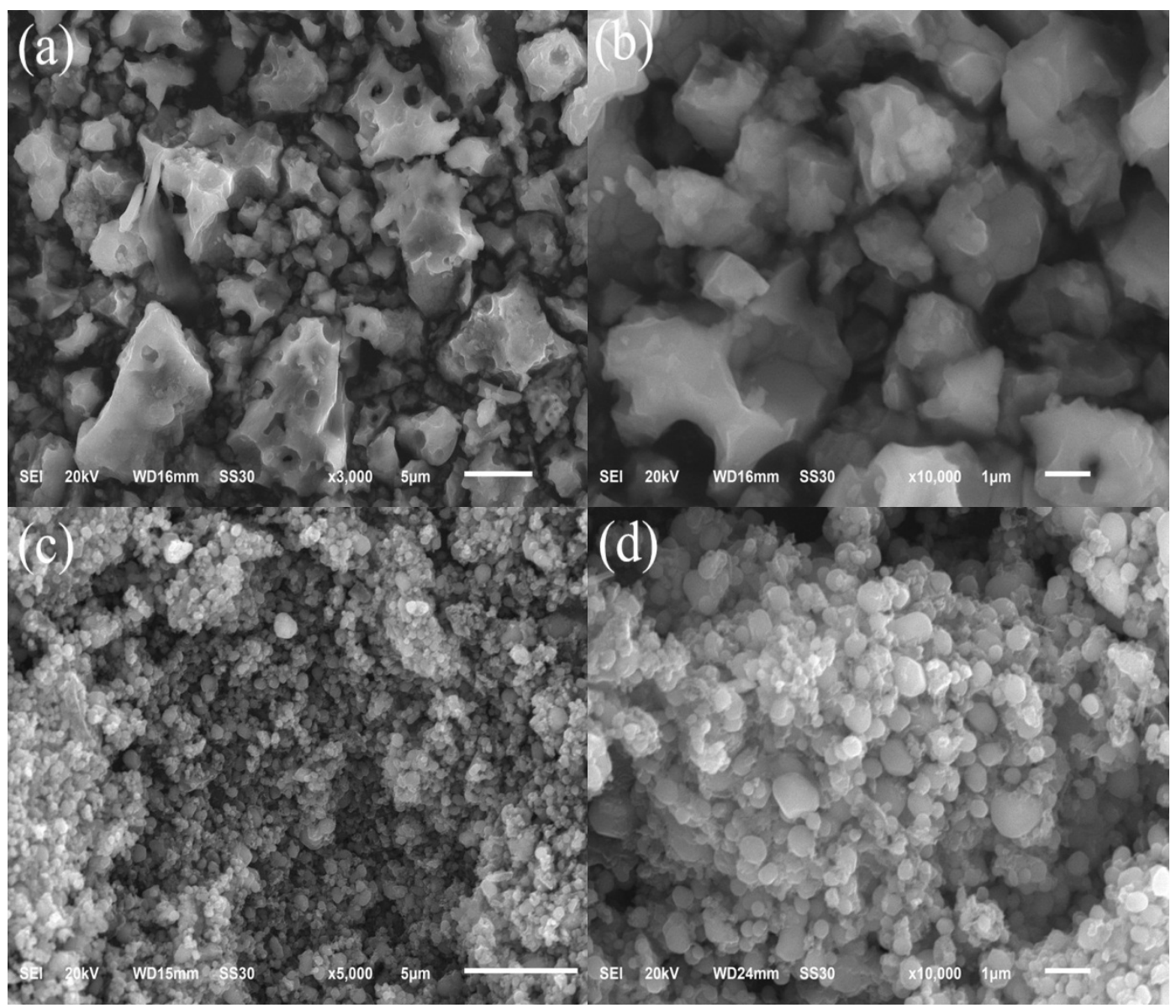

Fig. 2. SEM images of the samples: (a, b) $\mathrm{LiFeBO}_{3}$ and (c, d) $\mathrm{LiFeBO}_{3} / \mathrm{C}$.

The electrochemical performances of $\mathrm{LiFeBO}_{3}$ and $\mathrm{LiFeBO}_{3} / \mathrm{C}$ were measured via coin cell testing. Fig. $3(\mathrm{a}, \mathrm{b})$ showed the typical discharge/charge cycles of the as-prepared $\mathrm{LiFeBO}_{3}$ and $\mathrm{LiFeBO}_{3} / \mathrm{C}$ electrodes cycled between 1.0 and $4.6 \mathrm{~V}$ with a current density of $5 \mathrm{~mA} \mathrm{~g}^{-1}$ at room temperature, respectively. In the discharge curves, two voltage plateaus near at 3.4 and $1.6 \mathrm{~V}$ are clearly observed in all samples. $\mathrm{LiFeBO}_{3}$ electrode delivers an initial discharge capacity of 126.5 $\mathrm{mA} \mathrm{h} \mathrm{g}^{-1}$ (Fig.3c). The discharge capacity reduces to $99.9 \mathrm{~mA} \mathrm{~h} \mathrm{~g}^{-1}$ after 50 cycles and dropped to $86.4 \mathrm{~mA} \mathrm{~h} \mathrm{~g}^{-1}$ after 100 cycles. The capacity retention was $68.3 \%$ after 100 cycles. For $\mathrm{LiFeBO}_{3} / \mathrm{C}$, the initial discharge capacity was $139.7 \mathrm{~mA} \mathrm{~h} \mathrm{~g}^{-1}$ (Fig.3c). After 50 cycles, the discharge capacity dropped to $103.6 \mathrm{~mA} \mathrm{~h} \mathrm{~g}^{-1}$. After 100 cycles, the discharge capacity even could retain 99.1 $\mathrm{mAh} \mathrm{g}^{-1}$. It is obvious that carbon-coated samples $\left(\mathrm{LiFeBO}_{3} / \mathrm{C}\right)$ show improved cycling performance with higher specific capacities at the same cycle with the same current density as compared with the bare $\mathrm{LiFeBO}_{3}$. Obviously, carbon coating provides the improved conductivity and connectivity between the active particles present in the electrode, which give rise to improve the capacity of the material. 

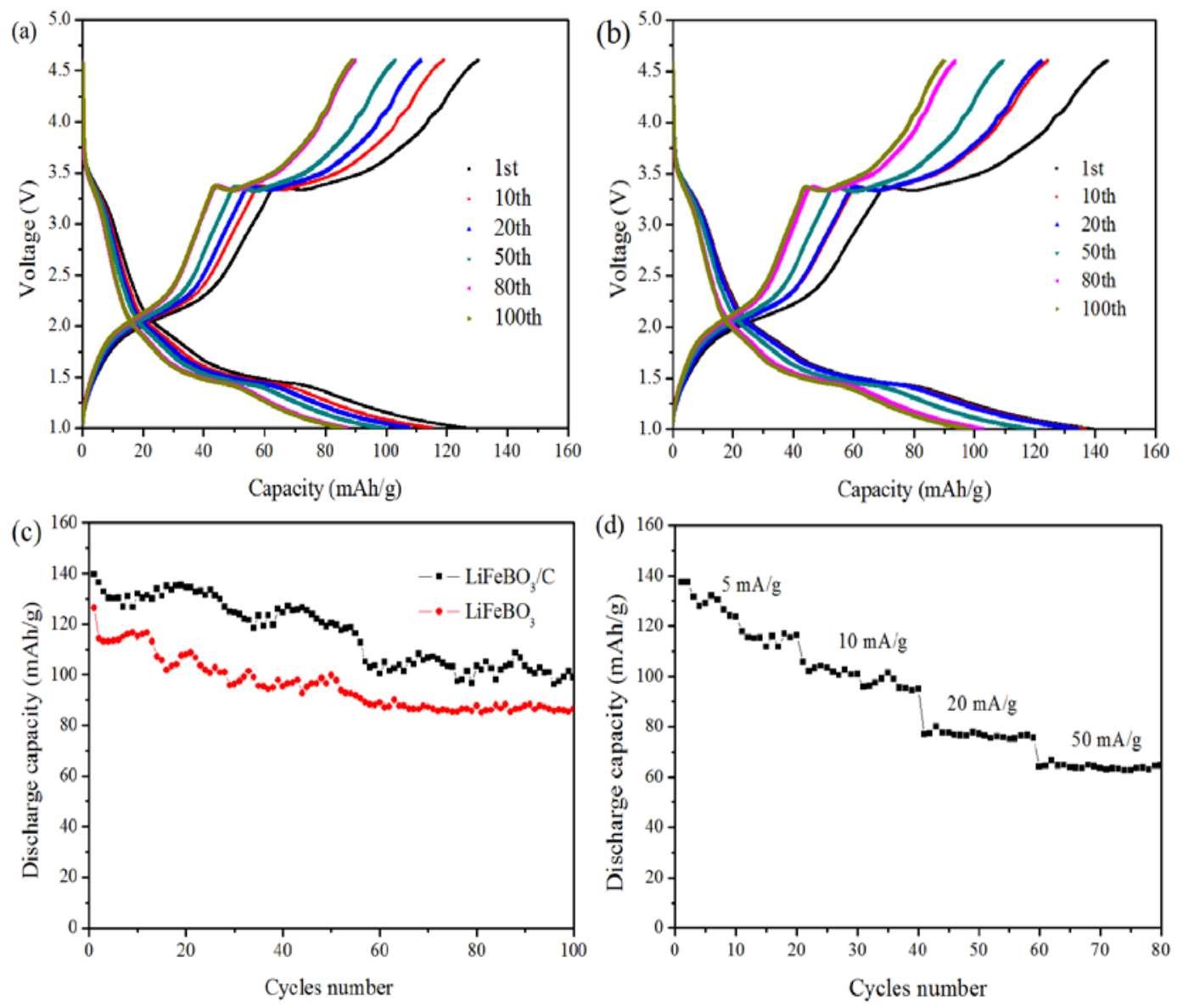

Fig. 3. Typical discharge/charge cycles of (a) $\mathrm{LiFeBO}_{3}$ and (b) $\mathrm{LiFeBO}_{3} / \mathrm{C}$, Cycling performance (c) of $\mathrm{LiFeBO}_{3}$ and $\mathrm{LiFeBO}_{3} / \mathrm{C}$ and rate performance (d) of $\mathrm{LiFeBO}_{3} / \mathrm{C}$.

Fig.3d shows the rate capability of the $\mathrm{LiFeBO}_{3} / \mathrm{C}$ electrode at various current densities. Apparently, the $\mathrm{LiFeBO}_{3} / \mathrm{C}$ electrode displays good capacity retention at different current densities. When the current rates were $5,10,20$, and $50 \mathrm{~mA} \mathrm{~g}^{-1}$, the specific capacities were 137.3, 101.9, 77.1, and $64.2 \mathrm{~mA} \mathrm{~h} \mathrm{~g}^{-1}$, respectively. This demonstrates that the $\mathrm{LiFeBO}_{3} / \mathrm{C}$ has great potential as high-rate anode materials in lithium-ion batteries.

\section{Conclusion}

$\mathrm{LiFeBO}_{3}$ and $\mathrm{LiFeBO}_{3} / \mathrm{C}$ were successfully prepared by a rheological phase reaction method. $\mathrm{LiFeBO}_{3} / \mathrm{C}$ displays the best electrochemical performance. It shows a large discharge capacity of $139.7 \mathrm{~mA} \mathrm{~h} \mathrm{~g}^{-1}$ at $5 \mathrm{~mA} \mathrm{~g}^{-1}$ with the capacity retention of $80.9 \%$ after 100 cycles, and good cycling stability at various current densities. Observed results demonstrated that the carbon coating on the surfaces of LMB can greatly enhance the discharge capacity due to the improved electric conductivity. The resurch results provides one possible direction for future cathode of lithium ion batteries. These results indicate that $\mathrm{LiFeBO}_{3} / \mathrm{C}$ could be a promising cathode material for lithium ion batteries.

\section{Acknowledgements}

This work was financially supported by the the project in the joint science and technology funds of Guizhou science and technology department, Anshun city people's government, and Anshun university (No: LKA[2012]02). 


\section{References}

[1] M. Pivko, M. Bele, E. Tchernychova, N.Z. Logar, R. Dominko, M. Gaberscek. Synthesis of Nanometric $\mathrm{LiMnPO}_{4}$ via a Two-Step Technique, Chem. Mater. 24 (2012) 1041-1047.

[2]S. Nishimura, M. Nakamura, R. Natsui, A. Yamada, New lithium iron pyrophosphate as 3.5 V-class cathode material for lithium ion battery, J. Am. Chem. Soc. 132 (2010) 13596-13597.

[3] V. Legagneur, Y. An, A. Mosbah, R. Portal, A. Le Gal La Salle, A. Verbaere, D. Guyomard, Y. Piffard. $\mathrm{LiMBO}_{3}(\mathrm{M}=\mathrm{Mn}, \mathrm{Fe}, \mathrm{Co})$ : synthesis, crystal structure and lithium deinsertion / insertion properties, Solid State Ionics. 139 (2001) 37-46.

[4] Y.Z. Dong, Y.M. Zhao, Z.D. Shi, X.N. An, P. Fu, L. Chen, The structure and electrochemical performance of $\mathrm{LiFeBO}_{3}$ as a novel Li-battery cathode material, Electrochimica Acta. 53 (2008) 2339-2345.

[5] A. Yamada, N. Lwane, S. Nishimura, Y. Koyama, I. Tanaka, Synthesis and electrochemistry of monoclinic $\mathrm{Li}\left(\mathrm{Mn}_{\mathrm{x}} \mathrm{Fe}_{1-\mathrm{x}}\right) \mathrm{BO}_{3}$ : a combined experimental and computational study, J. Mater. Chem. 21 (2011) 10690-10696.

[6] A. Yamada, N. Lwane, Y. Harada, S. Nishimura, Y. Koyama, I. Tanaka, Lithium Iron Borates as High-Capacity Battery Electrodes, Adv. Mater. 22 (2010) 3583-3587.

[7] D.H. Seo, Y.U. Park, S.W. Kim, I. Park, R.A. Shakoor, K. Kang. First-principles study on lithium metal borate cathodes for lithium rechargeable batteries, Phys. Rev. B. 83 (2011) 205127-1-8.

[8]Y.Z. Dong, Y.M. Zhao, P. Fu, H. Zhou, X.M. Hou, Phase relations of $\mathrm{Li}_{2} \mathrm{O}-\mathrm{FeO}-\mathrm{B}_{2} \mathrm{O}_{3}$ ternary system and electrochemical properties of $\mathrm{LiFeBO}_{3}$ compound, J. ALLOY. COMPD. 461 (2008) 585-590. 